\title{
The Effect of Authentic Problem - Based Learning in Enhancing Reading Comprehension
}

\author{
Halimatus Sa'diyah ${ }^{1, *}$, KhoirulAnwar $^{2}$, Agus Wardhono ${ }^{3}$ \\ ${ }^{1}$ Halimatus Sa'diyh. Universitas Muhammadiyah Gresik, \\ ${ }^{2}$ Khoirul Anwar. Universitas Muhammadiyah Gresik \\ ${ }^{3}$ Agus Wardhono. Universitas Muhammadiyah Gresik \\ *Corresponding author email: halimatuskusnan@gmail.com
}

\begin{abstract}
Limited background knowledge, lack of student motivation, limited vocabulary, and difficulties to comprehend materials are still problematic commonly for students' in reading comprehension. The purpose of this study is to enhance reading comprehension through authentic problem-based learning of eight grade students in SMPN 1 Babat. A mixed method design is employed with quasi-experimental of pre-test and post-test group experimental class and control class, and a survey to check students readiness which are analyzed quantitatively. The researchers are working to employ authentic problem- based learning by allotting materials contextually to real situation such as journey/trip, holiday and travelling videos then let students discuss story from the text to solve problems unconsciously. The result of T-test indicates that Authentic problem based learning was better than using convensional learning in reding comprehension. An interview of the respondents is also employed to see opinion of students related to affective aspects. Results show that there is significant result of the increasing comprehension of the students ( $\mathrm{p}$ is below 0.05). Data from questionnaire also show which most of the respondents rocket motivation and interested in reading comprehension in which they are enthusiastic to learn fun, easy, and active in class. Usefull procedures of implementation as well as further recommendations are also provided in this study.
\end{abstract}

Keywords: Authentic Problem Based Learning, Reading Comprehension.

\section{INTRODUCTION}

Based on previous research about authentic material for a decade focus on enhancing reading achievement.[1] and Reading is the most needed basic skill of all, so an individual can employ in every reality of life.[2] Studies show authentic materials can be involved by students' reading comprehension in the reading class activity. The difficulties in comprehending passage on reading is one of the common phenomena, it happened because many factors like as: the lack of students of motivation, the limited of the vocabulary and the difficult of the material.[3] mention that there are basically two types of language teaching and learning materials; authentic and pedagogic material. Using authentic materials successful in developing reading comprehension of students and involvement in reading class.[4] It refers to whether or not the text interests students to read and whether or not it is appropriate for their goals in learning English.[5] The use of authentic materials is sufficient to increase students' reading comprehension when they were used together that authentic tasks which contribute communicative enterprises. Students could concentrate on the lesson and actively enjaged in teaching and learning process. They can check detail information of the texts, deduct the meaning of unexpected words and understand info enterprise information when it is not explicitly stated[4]. Teaching reading using authentic materials be able to enhance students' comprehension of short functional text.[6] Reading comprehension of the Iranian intermediate EFL students can be enhanced by the side effect of authentic material. The use of authentic task-based authentic material in Turkish language course increase the reading comprehension, writing skills and writing motivation of primary school students were used together with authentic tasks which contributed communicative actitivies.

To drive the students here the researcher give some treatments and survey to leaners in experimental group of SMPN 1 Babat by giving authentic problem- based learning in studying reading [1]. the use of authentic materials is sufficient to increase students' reading comprehension when they were used together with authentic tasks which contribute communicative actitivies. Students could consentrate on the lesson and actively engaged in teaching and learning process. They were able to scan detail information of the texts, deduce the meaning of unfamiliar words and understand information when it is not explicitly stated. In this treatments, the researcher used authentic problembased learning according to students' 
problems/difficulties in studying reading. Giving kinds of short functional text and playing some videos which relate with the text, discuss to solve their problem with their friend in the group which those can help students in comprehending the text/passages easier than they just read the text on their book.

This present study focus on giving authentic problem-based learning in enhancing students' reading comprehension. With regard to the main intention of the present research by the following research questions:

1. What is the significance effect of authentic problem -based learning in enhancing students' reading comprehension achievement?

2. How can authentic problem - based learning enhance student's motivation in reading comprehension?

\section{LITERATURE REVIEW}

\subsection{Authentic Problem Based Learning}

Authentic material refers to those taken from real life sources and they are not designed for teaching and learning purposes. The most common expert of authentic materials which be able to used in the classroom are newspaper, magazine, songs, tv, radio, video and materials from the internet [7]. defines authentic texts as "real-life texts, not written for pedagogic processes". One of the main purposes of authentic materials in the classroom is to "expose" learners to as much real language as possible. Therefore, the students can gain real information and know what is going on in the world around them. "Authentic texts can be supporting because they are evidence that the language is used for real-life purposes by real people"[8]. Moreover, they have a positive effect on comprehension and learner satisfaction [5]. Thus, it can be implied that the use of authentic materials affect the students' reading comprehension also he determines that several studies have found out that authentic materials can improve reading development by offering students to new vocabulary and expression[9]
Problem based learning (PBL) is part of this custom of essential, factual learning. In PBL, students learn by solving problem and following on their experiences. [10] PBL is well appropriated to help students become active learners because it establishes learning. It has dual attention on helping students increase strategies and contruct knowledge. [11] A review of PBL is timely because issues of accessible thinking and lifelong learning have come to the fore in discussions of classroom reform. PBL is concentrate, experiential learning formulated around the investigation, explanation, and resolution of meaningful problems. In PBL, students work in small collaborative groups and study what they want to know in order to solve a problem. PBL is one of part of approves that include anchored instruction an project-based science [10]. There are at least two key issues that go to the heart of all of these approves to learning through problem solving.

\subsection{Reading Comprehension}

Reading is the instruction between a reader and a text to blend information from the reader's background knowledge, the aim the text to raise meaning. [12] Reading Comprehension: is the process of concurrently eliciting and formulating meaning through interaction and entanglement with written language.[13]

\section{METHODOLOGY}

The participated was conducted in SMP N 1 Babat. The data has been taken from 66 eightgrade students consisting of 33 males and 33 females with an age range between 13-14 years old. A non-random sampling method was used to select the experiment group and the control group. The researcher took two classes as the experiment class $=32$ students and the control class $=34$ students. English is considered a foreign language they learn but never use outside the classroom. Their languages of common use are Indonesian Language and Javanese Language.

TABLE 1. The Distribution of the Research Instruments

\begin{tabular}{|c|c|l|c|c|c|}
\hline Group & Class & Instrument & Treatment & Instrument & $\begin{array}{c}\text { Student's } \\
\text { number }\end{array}$ \\
\hline Experimental & VIII-A & Pre-test & $\begin{array}{c}\text { Authentic } \\
\text { problem- } \\
\text { based } \\
\text { learning }\end{array}$ & Post-test & \multirow{2}{*}{32} \\
\cline { 1 - 4 } Control & VIII-B & Pre-test & $\begin{array}{c}\text { Conventional } \\
\text { (textbook) }\end{array}$ & Post-test & 34 \\
\hline
\end{tabular}


In this study, the writer applayed a quantitative data analysis technique. Because this study was quasiexperimental; the instruments to assemble the data were or reading test and questionnaire. The researcher provided the questions for pre-test and post-test. Each test consists of twenty five questions.

It can be seen that the Pearson product- moment validity test with the results of $r$ with the range of $0,353-$ 0,776 , they are more than 0,349 (r TABLE $32(\mathrm{n}-2)$ ) and the significance values are smaller than 0.05 . Thus, the questions used by each pre-test and post-test are declared valid.

TABLE 2. a.. Recap The Results Of Pre-Test (Experiment class)

\begin{tabular}{|c|c|c|c|}
\hline Item & Pearson Correlation & Significance & Meaning \\
\hline No.1 &, $696^{* *}$ &, 000 & Valid \\
\hline No.2 & ,359* &, 044 & Valid \\
\hline No.3 &, $378^{*}$ &, 033 & Valid \\
\hline No.4 &, $610^{* * *}$ & ,000 & Valid \\
\hline No.5 &, $374^{*}$ & ,035 & Valid \\
\hline No.6 &, $356^{*}$ &, 045 & Valid \\
\hline No.7 &, $353^{*}$ &, 047 & Valid \\
\hline No.8 & ,399* &, 024 & Valid \\
\hline No.9 & ,394* & 025 & Valid \\
\hline No.10 &, $637^{* *}$ &, 000 & Valid \\
\hline No.11 & ,386* & ,029 & Valid \\
\hline No.12 &, $591^{* *}$ &, 000 & Valid \\
\hline No.13 &, $503^{* * *}$ & ,003 & Valid \\
\hline No.14 &, $776^{* * *}$ &, 000 & Valid \\
\hline No. 15 &, $583^{* *}$ & ,000 & Valid \\
\hline No.16 &, $354^{*}$ &, 047 & Valid \\
\hline No.17 &, $462^{* *}$ & ,008 & Valid \\
\hline No.18 &, $377^{*}$ &, 033 & Valid \\
\hline No.19 &, $527^{* *}$ & ,002 & Valid \\
\hline No.20 & ,399* &, 024 & Valid \\
\hline No.21 & ,368* & ,038 & Valid \\
\hline No.22 &, $451^{* * *}$ & ,010 & Valid \\
\hline No.23 &, $527^{* * *}$ & ,002 & Valid \\
\hline No.24 & ,399* & ,024 & Valid \\
\hline No. 25 &, $481^{* *}$ & ,005 & Valid \\
\hline
\end{tabular}

TABLE 2.b. Recap The Results Of Post-Test (Experiment class)

\begin{tabular}{|c|c|c|c|}
\hline Item & Pearson Correlation & Significance & Meaning \\
\hline No. 1 &, $903^{* *}$ &, 000 & Valid \\
\hline No. 2 &, $672^{* *}$ &, 000 & Valid \\
\hline No.3 &, $494^{* *}$ &, 004 & Valid \\
\hline No.4 &, $504^{* *}$ &, 003 & Valid \\
\hline
\end{tabular}




\begin{tabular}{|c|c|c|c|}
\hline No.5 &, $437^{*}$ & ,012 & Valid \\
\hline No.6 &, $708^{* *}$ & ,000 & Valid \\
\hline No.7 &, $424^{*}$ & 016 & Valid \\
\hline No.8 &, $407^{*}$ & ,021 & Valid \\
\hline No.9 &, $383^{*}$ & 030 & Valid \\
\hline No.10 &, $903^{* *}$ & ,000 & Valid \\
\hline No.11 &, $564^{* *}$ & ,001 & Valid \\
\hline No.12 &, $502^{* *}$ & ,003 & Valid \\
\hline No.13 &, $466^{* *}$ & ,007 & Valid \\
\hline No.14 & ,690** & ,000 & Valid \\
\hline No.15 &, $627^{* *}$ & ,000 & Valid \\
\hline No.16 &, $567^{* *}$ & ,001 & Valid \\
\hline No.17 &, $387^{*}$ & ,029 & Valid \\
\hline No. 18 &, $486^{* *}$ & ,005 & Valid \\
\hline No.19 &, $418^{*}$ & ,017 & Valid \\
\hline No. 20 &, $624^{* *}$ & ,000 & Valid \\
\hline No.21 &, $534^{* *}$ & ,002 & Valid \\
\hline No. 22 &, $452^{* *}$ & ,009 & Valid \\
\hline No. 23 & $397^{*}$ & 024 & Valid \\
\hline No. 24 &, $357^{*}$ & ,045 & Valid \\
\hline No. 25 &, $381^{*}$ & 031 & Valid \\
\hline
\end{tabular}

The questionnaire was used to know the motivation of the students that used Authentic problem- based learning in the learning process. It consists of 20 item statements. Based on TABLE 3 , the validity test results of the motivation questionnaire learning with Authentic problem- based learning shows the range of $0.418-0.792$, they are more than 0.396 (r TABLE $25(\mathrm{n}-2)$ ) and the significant values are smaller than 0.05 , so 20 statements of the motivation questionnaire are declared valid and can be used for research.

TABLE 3. The Validity of Motivation Questionnaire

\begin{tabular}{|c|c|c|c|}
\hline Items & Pearson Correlation & Significance & Meaning \\
\hline Item 1 &, $775^{* *}$ & 0,000 & Valid \\
\hline Item 2 &, $628^{* *}$ & 0,000 & Valid \\
\hline Item 3 &, $839^{* *}$ & 0,000 & Valid \\
\hline Item 4 &, $631^{* *}$ & 0,000 & Valid \\
\hline Item 5 &, $834^{* *}$ & 0,000 & Valid \\
\hline Item 6 &, $497^{* *}$ & 0,004 & Valid \\
\hline Item 7 &, $746^{* *}$ & 0,000 & Valid \\
\hline Item 8 &, $731^{* *}$ & 0,000 & Valid \\
\hline Item 9 &, $759^{* *}$ & 0,000 & Valid \\
\hline Item 10 &, $524^{* *}$ & 0,002 & Valid \\
\hline
\end{tabular}




\begin{tabular}{|c|c|c|c|}
\hline Item 11 &, $362^{*}$ & 0,042 & Valid \\
\hline Item 12 &, $743^{* *}$ & 0,000 & Valid \\
\hline Item 13 &, $703^{* *}$ & 0,000 & Valid \\
\hline Item 14 &, $751^{* *}$ & 0,000 & Valid \\
\hline Item 15 &, $712^{* *}$ & 0,000 & Valid \\
\hline Item 16 &, $688^{* *}$ & 0,000 & Valid \\
\hline Item 17 &, $670^{* *}$ & 0,000 & Valid \\
\hline Item 18 &, $747^{* *}$ & 0,000 & Valid \\
\hline Item 19 &, $765^{* *}$ & 0,000 & Valid \\
\hline Item 20 &, $703^{* *}$ & 0,000 & Valid \\
\hline
\end{tabular}

Based on TABLE, the Cronbach's alpha value of pre-test on experimental class (0.604); pre-test on control class (0.594); post-test on experimentall class (0.759) and post-test on control class (0.707) show all variables are greater than 0.700 , so it can be known that the questions used for pre-test and posttest are reliable.

TABLE 4. The Reliability Test

\begin{tabular}{|c|c|c|}
\hline Groups & Cronbach's Alpha & N of Items \\
\hline Pretest of Experiment &, 604 & 25 \\
\hline Pretest of Control &, 594 & 25 \\
\hline Posttest of Experiment &, 759 & 25 \\
\hline Posttest of Control &, 707 & 25 \\
\hline
\end{tabular}

Based on TABLE 5, the Cronbach's alpha value of the motivation questionnaire amounted to 0,931 , it means such a test has a high reliability because it has exceeded 0.7 of provisions, so that 20 statements of the questionnaire have been declared reliable and can be used for research.

TABLE 5. The Reliability of Motivation Questionnaire

\begin{tabular}{|c|c|}
\hline Cronbach's Alpha & N of Items \\
\hline, 931 & 20 \\
\hline
\end{tabular}

\section{RESULT}

\subsection{Normality Test}

In normality test, the researcher used KolmogorovSmirnov. If the value of Asymp.Sig.(2-tailed) is more than 0.05 it can be said that the data presented normal distribution. On the contrary, if the data calculation of the one-sample Kolmogorov-Smirnov delivers a value below 0.05 , then the regression model did not meet the assumption of normality.
From TABLE 6, it can be seen that the significance value of pre test on experiment class is 0.073 , the significance value of pre test on control class is 0.164 , the significance value on post-test of experiment class is 0.101 , and the significance value of the post-test on control class is 0.062. Those numbers show significance for all variables are above 0.05 , it can be known that the results of pretest have the normal distribution data. 
TABLE 6. Normality Test

\begin{tabular}{|l|l|r|r|r|r|}
\hline \multicolumn{2}{|c|}{} & $\begin{array}{c}\text { Authentic Problem } \\
\text { Based Learning } \\
\text { (Pre test) }\end{array}$ & $\begin{array}{c}\text { Conventional } \\
\text { Learning (Pre } \\
\text { test) }\end{array}$ & $\begin{array}{c}\text { Authentic Problem } \\
\text { Based Learning } \\
\text { (Post test) }\end{array}$ & $\begin{array}{c}\text { Conventional } \\
\text { Learning (Post } \\
\text { test) }\end{array}$ \\
\hline $\mathrm{N}$ & Mean & 32 & 34 & 32 & 34 \\
\hline Poisson Parameter, & 60,38 & 59,41 &, 178 & $, 217,88$ &, 183 \\
\hline \multirow{2}{*}{ Most Extreme Differences } & Absolute &, 217 &, 217 &, 183 & 70,71 \\
\cline { 2 - 7 } & Positive &,- 257 &,- 224 &,- 224 &, 181 \\
\cline { 2 - 7 } & Negative & 1,225 & 1,038 & 1,033 &, 237 \\
\hline Kolmogorov-Smirnov Z & &, 100 &, 231 &, 236 & 1,058 \\
\hline Asymp. Sig. (2-tailed) & & & & &, 213 \\
\hline
\end{tabular}

The significance value of Students' Motivation Questionnaire using the Authentic problem based learning in Experiment class is 0.400 with the description in TABLE 7 . That number shows the significance for the variable is above 0.05 , it can be concluded that the result of Students' Motivation Questionnaire using the cooperative-instructional video in Experimental class has a normal distribution

TABLE 7. Normality of Students' Motivation Questionnaire

\begin{tabular}{|l|l|r|}
\hline \multicolumn{2}{|c|}{ One-Sample Kolmogorov-Smirnov Test } \\
\hline \multicolumn{2}{|c|}{} & $\begin{array}{l}\text { Penggunaan Autentic Material Using } \\
\text { Problem Based Learning Pada Siswa } \\
\text { Kelas VIII A }\end{array}$ \\
\hline N & \multicolumn{2}{c|}{32} \\
\hline Poisson Parametera,b & Mean & 76,81 \\
\hline Most Extreme Differences & Absolute &, 158 \\
\cline { 2 - 4 } & Positive &,- 158 \\
\cline { 2 - 4 } & Negative &, 895 \\
\hline Kolmogorov-Smirnov Z &, 400 \\
\hline Asymp. Sig. (2-tailed) & & \\
\hline
\end{tabular}

\subsection{Homogeneity Test}

Having known the level of normality data, the next test is homogeneity. Homogeneity test is used to know the level of similarity of variance between two groups' namely experimental group and control group. To accept or reject the hypothesis by comparing sig on Levene's statistic with 0.05 ( $\mathrm{sig}>$ 0.05). The result of the TABLE 8 shows the significance of all the test are above 0.05 , indicating that the variances of the data are homogeneous.

TABLE 8. Homogeneity Test

\begin{tabular}{|c|c|c|c|c|c|}
\hline Groups & Test & $\begin{array}{c}\text { Levene's } \\
\text { Statistik }\end{array}$ & df1 & df2 & Sig \\
\hline $\begin{array}{c}\text { Experiment and } \\
\text { Control }\end{array}$ & Pre & 1,189 & 1 & 64 & 0.280 \\
\hline $\begin{array}{c}\text { Experiment and } \\
\text { Control }\end{array}$ & Post & 0,093 & 1 & 64 & 0.761 \\
\hline Experiment & Pre and Post & 0,941 & 1 & 62 & 0.336 \\
\hline Control & Pre and Post & 5.769 & 1 & 66 & 0.191 \\
\hline
\end{tabular}




\subsection{Student's Learning Result}

The result of learning with Authentic problem based learning is better than learning with conventional method. Mean of experiment class increase from 60,38 to 75.88 while for control class 59,41 to 70.71 . Increased grade point average where the experimental class is higher than the control class. The data presented in TABLE 9.

TABLE 9. Students Learning Result

\begin{tabular}{|c|c|c|c|c|c|c|}
\hline Group & Test & $\mathrm{N}$ & Min & Max & Mean & $\begin{array}{c}\text { Std. } \\
\text { Deviation }\end{array}$ \\
\hline Experimental & Pre & 32 & 48 & 80 & 60.38 & 8.400 \\
\hline & Post & 32 & 64 & 92 & 75.88 & 7.430 \\
\hline Control & Pre & 34 & 36 & 76 & 59.41 & 10.000 \\
\hline & Post & 34 & 56 & 88 & 70.71 & 6.873 \\
\hline
\end{tabular}

The motivation questionnaire using five-point Likert-type scales. Items on the scales are anchored at $1=$ strongly disagree, $2=$ disagree, $3=$ neutral $4=$ agree and $5=$ strongly agree. The learning motivation of students which used Authentic problem-based learning of the students in experiment class show the average answer of the positive statement on item 1 to item 10 has an average value of 3.93. It means that the students of experimental class agree with the use of APBL. While, for negative statements in item 11 to item 20 has an averaged value of 3.71 . It means that the students of experimental class disagree with the negative statements of the questionnaire asked by the researcher. This means that students become motivated in the use of APBL on English subject. It is according to the description in TABLE 10 as follows.

TABLE 10. Result of Students' Learning Motivation Questionnaire

\begin{tabular}{|c|c|c|c|c|c|}
\hline $\begin{array}{c}\text { Number of } \\
\text { Questionnaire }\end{array}$ & $\mathrm{N}$ & Min & Max & Mean & $\begin{array}{c}\text { Std. } \\
\text { Deviation }\end{array}$ \\
\hline 1 & 32 & 3 & 5 & 4.31 & 0.535 \\
\hline 2 & 32 & 2 & 5 & 4.44 & 0.801 \\
\hline 3 & 32 & 2 & 5 & 3.78 & 0.608 \\
\hline 4 & 32 & 2 & 5 & 4,19 & 0.896 \\
\hline 5 & 32 & 2 & 4 & 3.41 & 0.789 \\
\hline 6 & 32 & 3 & 5 & 4.31 & 0.535 \\
\hline 7 & 32 & 2 & 5 & 4.44 & 0.801 \\
\hline 8 & 32 & 2 & 5 & 3.78 & 0.608 \\
\hline 9 & 32 & 2 & 5 & 4.19 & 0.896 \\
\hline 10 & 32 & 2 & 4 & 3.41 & 0.798 \\
\hline 11 & 32 & 2 & 5 & 3.16 & 1.019 \\
\hline 12 & 32 & 3 & 4 & 3,84 & 0.369 \\
\hline 13 & 32 & 3 & 4 & 3.84 & 0.369 \\
\hline 14 & 32 & 2 & 4 & 3.75 & 0.508 \\
\hline 15 & 32 & 2 & 4 & 3.84 & 0.3491 \\
\hline 16 & 32 & 2 & 4 & 3.53 & 0.718 \\
\hline 17 & 32 & 3 & 5 & 3,94 & 0.564 \\
\hline 18 & 32 & 2 & 5 & 3.53 & 0.803 \\
\hline 19 & 32 & 2 & 5 & 3.75 & 0.718 \\
\hline 20 & 32 & 3 & 4 & 3.84 & 0.369 \\
\hline
\end{tabular}




\subsection{Hypothesis Test}

After the data are stated normal and homogeneous, then both requirements are fulfilled for the t-test. This test is done to take the decision whether the hypothesis is accepted or rejected. The hypotheses of this study are:

Ho : The use of APBL cannot build the students' motivation and accomplisement in reading comprehension

H1 : The use of APBL can build the students' motivation and accamplisement in reading comprehension

\subsection{The Significant Difference Value of Pre-Test between Experiment class and Control class}

The analysis of independent-Sample t-test of pretest in the experimental class and control class is aimed to know whether there is significant difference in the value of pre-test in the experimental class and the control class. The conclusion of the study is stated significant if $t_{\text {count }}$ $>\mathrm{t}_{\mathrm{TABLE}}$ at significance level of $5 \%$ and the value of $\mathrm{p}<0.05$.

In the Independent sample test obtained a significant value (2-tailed) of 0.674 and a calculated value of 0.422 and a t-value of 66 (n-2) obtained at a $5 \%$ significance level of 1.998 . Because the value of $\mathrm{t}_{\text {count }}<\mathrm{t}_{\mathrm{TABLE}}(0.422<1.998)$ and sig. $>0.05(0.674>$ $0.05)$. So it can be concluded that there is no significant difference between the pretest of learning outcomes in learning that uses Authentic Problem Based Learning and the pretest of learning outcomes in learning using Conventional Learning. It is according to the description in TABLE 11 as follows.

TABLE 11. T-Test Calculation of Pre-Test Results between Experimental Class and Control Class

\begin{tabular}{|c|c|c|c|c|c|c|c|c|c|c|}
\hline \multicolumn{11}{|c|}{ Independent Samples Test } \\
\hline & & \multicolumn{2}{|c|}{$\begin{array}{l}\text { Levene's } \\
\text { Test for } \\
\text { Equality } \\
\text { of } \\
\text { Variances }\end{array}$} & \multicolumn{7}{|c|}{ t-test for Equality of Means } \\
\hline & & \multirow[b]{2}{*}{$\mathrm{F}$} & \multirow[b]{2}{*}{ Sig. } & \multirow[b]{2}{*}{$\mathrm{T}$} & \multirow[b]{2}{*}{$\mathrm{df}$} & \multirow{2}{*}{$\begin{array}{l}\text { Sig. (2- } \\
\text { tailed) }\end{array}$} & \multirow{2}{*}{$\begin{array}{c}\text { Mean } \\
\text { Difference }\end{array}$} & \multirow{2}{*}{$\begin{array}{l}\text { Std. Error } \\
\text { Difference }\end{array}$} & \multicolumn{2}{|c|}{$\begin{array}{l}95 \% \text { Confidence } \\
\text { Interval of the } \\
\text { Difference }\end{array}$} \\
\hline & & & & & & & & & Lower & Upper \\
\hline \multirow[t]{2}{*}{$\begin{array}{l}\text { Pre test } \\
\text { Value }\end{array}$} & $\begin{array}{l}\text { Equal } \\
\text { variances } \\
\text { assumed } \\
\end{array}$ & 1,189 & ,280 &,- 422 & 64 &, 674 &,- 963 & 2,281 & $-3,593$ & 5,519 \\
\hline & $\begin{array}{l}\text { Equal } \\
\text { variances } \\
\text { not assumed }\end{array}$ & & &,- 425 & 63,209 & ,673 &,- 963 & 2,269 & $-3,570$ & 5,496 \\
\hline
\end{tabular}

\subsection{The Significant Difference Value of Post-Test between Experiment class and Control class}

The analysis of independent-Sample t-test of posttest in the experimental class and the control class is aimed to determine whether there is significant difference in the value of post-test in the experiment class and the control class. The conclusion of the study is stated significant if $t_{\text {count }}>t_{\text {TABLE }}$ at significance level of $5 \%$ and the value of $p<0.05$.

In the Independent sample test obtained a significant value (2-tailed) of 0.005 and a $t_{\text {count }}$ of
2.936 and obtained a $\mathrm{t}_{\mathrm{TABLE}}$ value of $\mathrm{df} 66(\mathrm{n}-2)$ at a $5 \%$ significance level of 1.998 . Because $t_{\text {count }}>t_{\text {TABLE }}$ $(2,936>1,998)$ and sig. $<0.05(0.005<0.05)$. Thus, $\mathrm{H}_{0}$ is rejected and $\mathrm{H}_{1}$ is accepted. So it can be concluded that there is a significant difference between the post-test of learning outcomes in learning that uses the Authentic Problem Based Learning of Class VIII A students and the post-test of learning outcomes in learning using Conventional Learning of Class VIII B students of SMP Negeri 1 Babat Lamongan. It is according to the description in TABLE 12 as follows. 
TABLE 12. T-Test Calculation of Post-Test Results between Experiment Class and Control Class

\begin{tabular}{|c|c|c|c|c|c|c|c|c|c|}
\hline \multicolumn{10}{|c|}{ Independent Samples Test } \\
\hline & \multicolumn{2}{|c|}{\begin{tabular}{|c|} 
Levene's Test for \\
Equality of \\
Variances \\
\end{tabular}} & \multicolumn{7}{|c|}{ t-test for Equality of Means } \\
\hline & \multirow[b]{2}{*}{ F } & \multirow[b]{2}{*}{ Sig. } & \multirow[b]{2}{*}{$\mathrm{t}$} & \multirow[b]{2}{*}{$\mathrm{df}$} & \multirow{2}{*}{$\begin{array}{l}\text { Sig. (2- } \\
\text { tailed) }\end{array}$} & \multirow{2}{*}{$\begin{array}{c}\text { Mean } \\
\text { Difference }\end{array}$} & \multirow{2}{*}{$\begin{array}{l}\text { Std. Error } \\
\text { Difference }\end{array}$} & \multicolumn{2}{|c|}{$\begin{array}{l}95 \% \text { Confidence } \\
\text { Interval of the } \\
\text { Difference }\end{array}$} \\
\hline & & & & & & & & Lower & Upper \\
\hline \multirow{2}{*}{\begin{tabular}{|l|l|} 
Post test & $\begin{array}{l}\text { Equal variances } \\
\text { assumed }\end{array}$ \\
Value & $\begin{array}{l}\text { Equal variances } \\
\text { not assumed }\end{array}$ \\
\end{tabular}} & ,093 &, 761 & 2,936 & 64 & ,005 & 5,169 & 1,761 & 1,652 & 8,686 \\
\hline & & & 2,929 & 62 & ,005 & 4,600 & 1,765 & 1,642 & 8,696 \\
\hline
\end{tabular}

\subsection{The Significant Difference Value of Pre test and Post test in Experiment Class} The analysis of independent-Sample t-test of pretest and post-test in the experiment class aims to determine whether there is significant difference in the value of pre-test and post-test in the experiment class. The conclusions of the study stated significant if $\mathrm{t}_{\text {count }}>\mathrm{t}_{\mathrm{TABLE}}$ at significance level of $5 \%$ and a value of $\mathrm{p}<0.05$.

In the Independent sample test obtained a significant value (2-tailed) of 0,000 and a $t_{\text {count }}$ of
7.818 and obtained a $\mathrm{t}_{\text {TABLE }}$ value of $\mathrm{df} 66(\mathrm{n}-2)$ at a $5 \%$ significance level of 1,999 . Because $t_{\text {count }}>t_{\text {TABLE }}$ $(7,818>1,999)$ and sig. $<0.05(0,000<0.05)$. So it can be summarized that there is a significant difference between the pretest and posttest scores on learning outcomes in learning using Authentic Problem Based Learning in class VIII A students at SMP Negeri 1 Babat Lamongan or $\mathrm{H}_{0}$ is rejected and $\mathrm{H}_{1}$ is accepted.It is according to the description in TABLE 13 as follows.

TABLE 13. T-Test Calculation between Pretest and Post test Result of Experiment Class

\begin{tabular}{|c|c|c|c|c|c|c|c|c|c|c|}
\hline \multicolumn{11}{|c|}{ Independent Samples Test } \\
\hline & & \multicolumn{2}{|c|}{$\begin{array}{l}\text { Levene's Test } \\
\text { for Equality of } \\
\text { Variances }\end{array}$} & \multicolumn{7}{|c|}{ t-test for Equality of Means } \\
\hline & & \multirow[b]{2}{*}{$\mathrm{F}$} & \multirow[b]{2}{*}{ Sig. } & \multirow[b]{2}{*}{$\mathrm{t}$} & \multirow[b]{2}{*}{ df } & \multirow{2}{*}{$\begin{array}{l}\text { Sig. (2- } \\
\text { tailed) }\end{array}$} & \multirow{2}{*}{$\begin{array}{c}\text { Mean } \\
\text { Difference }\end{array}$} & \multirow{2}{*}{$\begin{array}{l}\text { Std. Error } \\
\text { Difference }\end{array}$} & \multicolumn{2}{|c|}{$\begin{array}{l}\text { 95\% Confidence Interval } \\
\text { of the Difference }\end{array}$} \\
\hline & & & & & & & & & Lower & Upper \\
\hline \multirow[t]{2}{*}{$\begin{array}{l}\text { Class } \\
\text { Experimenta } \\
1 \text { (VIII-A) }\end{array}$} & $\begin{array}{l}\text { Equal } \\
\text { variances } \\
\text { assumed }\end{array}$ & 941 & ,336 & 7,818 & 62 & ,000 & 15,500 & 1,983 & 11,537 & 19,463 \\
\hline & $\begin{array}{l}\text { Equal } \\
\text { variances not } \\
\text { assumed }\end{array}$ & & & 7,818 & 61,090 &, 000 & 15,500 & 1,983 & 11,536 & 19,464 \\
\hline
\end{tabular}

\subsection{The Significant Difference Value of Pre test and Post test in Control Class}

The analysis of independent-Sample t-test of the pretest and the posttest in the control class aims to determine whether there is significant difference in the value of the pretest and the posttest in the control class. The conclusions of the study stated significant if tcount $>\mathrm{tTABLE}$ at significance level of $5 \%$ and a value of $\mathrm{p}<0.05$.

$\mathrm{H}_{0}$ : There is no significant difference between the pretest and posttest scores on learning outcomes in learning that use Conventional Learning of class VIII B students in SMP Negeri 1 Babat-Lamongan. $\mathrm{H}_{1}$ : There is a significant difference between the pretest and posttest scores on learning outcomes in learning that use Conventional Learning of class VIII B students in SMP Negeri 1 Babat-Lamongan.

The Independent sample test obtained a significant value (2-tailed) is 0.024 , the value of $t_{\text {count }}$ is 2.326 and the value of $\mathrm{t}_{\mathrm{TABLE}}$ of $\mathrm{df} 66(\mathrm{n}-2)$ at the significance level of $5 \%$ is 2.011 . Because the value of $\mathrm{t}_{\text {count }}>\mathrm{t}_{\mathrm{TABLE}}(5.427>2.011)$ and sig. $<0.05$ $(0.000<0.05)$. Thus, $\mathrm{H}_{0}$ is rejected and $\mathrm{H}_{1}$ is accepted. This indicates that there is a significant difference between pre-test and post-test result of students in control class who learn without using cooperative-instructional video. It is according to the description in TABLE 14 as follows. 
TABLE 14. T-Test Calculation between Pretest and Post test Result of Control Class

\begin{tabular}{|c|c|c|c|c|c|c|c|c|c|c|}
\hline \multicolumn{11}{|c|}{ Independent Samples Test } \\
\hline & & \multicolumn{2}{|c|}{$\begin{array}{l}\text { Levene's Test } \\
\text { for Equality of } \\
\text { Variances }\end{array}$} & \multicolumn{7}{|c|}{ t-test for Equality of Means } \\
\hline & & \multirow[b]{2}{*}{$\mathrm{F}$} & \multirow[b]{2}{*}{ Sig. } & \multirow[b]{2}{*}{$\mathrm{t}$} & \multirow[b]{2}{*}{ df } & \multirow{2}{*}{$\begin{array}{l}\text { Sig. (2- } \\
\text { tailed) }\end{array}$} & \multirow{2}{*}{$\begin{array}{c}\text { Mean } \\
\text { Differen } \\
\text { ce }\end{array}$} & \multirow{2}{*}{$\begin{array}{l}\text { Std. Error } \\
\text { Difference }\end{array}$} & \multicolumn{2}{|c|}{$\begin{array}{l}95 \% \text { Confidence } \\
\text { Interval of the } \\
\text { Difference }\end{array}$} \\
\hline & & & & & & & & & Lower & Upper \\
\hline \multirow[t]{2}{*}{$\begin{array}{l}\text { Class Control } \\
\text { (VIII B) }\end{array}$} & $\begin{array}{l}\text { Equal } \\
\text { variances } \\
\text { assumed }\end{array}$ & $\begin{array}{r}5,76 \\
9\end{array}$ & ,191 & 5,427 & 66 & ,000 & 11,294 & 2,081 & 7,139 & 15,449 \\
\hline & $\begin{array}{l}\text { Equal } \\
\text { variances } \\
\text { not } \\
\text { assumed }\end{array}$ & & & 5,427 & 58,490 & ,000 & 11,294 & 2,081 & 7,129 & 15,459 \\
\hline
\end{tabular}

\section{DISCUSSION}

This study purpose to determine the effectiveness of learning using the authentic problem -based learning on students' motivation and learning outcomes in reading comprehension. Based on the background research, the literature review and the data processing results of the study show there are differences in learning outcomes significantly between learners who were taught using the authentic problem-based learning with learners who were taught using conventional learning (textbook) in which students are given learning using the authentic problem-based learning obtain the learning outcomes higher than students who were given conventional learning (textbook).

The research question asks whether the use of authentic problem based learning have any effect in enhancing students' reading comprehension. One of the main aims of this study was to find out the effect of authentic problem based learning in enhancing reading comprehension. To answer this research question, the result obtained from the pre-test and post-test that the means of the authentic problem based learning in the post-test was higher that the pre-test. In other word, the use of authentic problem based learning in experimental group students (VIII A) get higher score after get treatment from the researcher than in pre-test. The researcher gave some treatments according to students' problems in studying reading; played kind of videos about holiday/trip, journey and travelling. It helped students in comprehending the story in passages with relate TABLE context that is one of students' lack. They cannot comprehend the passages because they thought that they cannot relate with the story so when they read the passages and watched the video simultaneously, they were easier to comprehend the passages. On the other aims of this study was to find out the use of authentic problem-based learning in enhancing reading comprehension according to the teachers' explanation that they were only focus on their curriculum or SKL, they were not understanding their students' needs and lacks. Meanwhile, students have any different level to comprehend the text whether they discuss in a group, they will share, take and give experience each other to solve the problem in the text but when the teacher gives other innovative way to help students in this case, the students felt that they are noticed by their teacher and they have support to get better score in reading comprehension.

\section{CONCLUSION}

The purpose of this study was to explore the effect of authentic based learning in enhancing students' reading comprehension accomplishment and the student's motivation The data analysis and findings of this research revealed that use authentic problem based learning has any effect on experimental group students, it showed on the result of post-test which experimental group were given treatment. Therefore, the first null hypothesis was rejected and the second one was accepted. Based on the result, the use of authentic problem based learning have any effect in enhancing students' reading comprehension.

Student motivation in comprehension in recount text of the sentence in the theme of travelling, holiday, and journey subjects English using learning Authentic Problem -Based Learning have a very significant influence, this is proved by the assessment of student questionnaire responses (motivation) after a given treatment learning use of Authentic Problem-Based Learning that is the average score of students ' answers-value of 3.93 or rounded up to 4 i.e. in the category of agree, in 
addition, students also feel happy, active, and it is easier to understand the reading, so it can be concluded that by using the learning Authentic Problem-Based Learning can improve student learning outcomes and motivate students in reading recount text with the theme of travelling, holiday, and journey.

\section{REFERENCES}

[1] R. Desitarahmi, "Using Authentic Materials To Improve Reading," pp. 1-175, 2013.

[2] S. Dilek Belet Boyaci and M. Güner, "The impact of authentic material use on development of the reading comprehension, writing skills and motivation in language course," Int. J. Instr., vol. 11, no. 2, pp. 351368, 2018.

[3] B. Y. Cahyono, "The Teaching of EFL Vocabulary in the Indonesian Context: The State Of The Art," TEFLIN J., vol. 19, no. 1, pp. 1-17, 2008.

[4] R. Desitarahmi, "Using Authentic Materials To Improve Reading," no. 06202244124, pp. 1-175, 2013.

[5] A. Lazaro, Teaching Reading Skills. 2013.

[6] S. A. Berardo, "The Use of Authentic Materials in the Teaching of Reading," Read. Matrix An Int. Online J., vol. 6, no. 2, pp. 60-69, 2006.

[7] L. T. Journals, "Vwxghqv $\mid$ lghd hqfrxdudjh wkhp wr uhodwh wkhpvhoyhv zlwk uhdo," vol. 10, no. 1, pp. 1-17, 2017.

[8] R. Hamed, A. Azri, and M. H. Al-rashdi, "The Effect Of Using Authentic Materials In Teaching," Int. J. Sci. Technol. Res., vol. 3, no. 10, pp. 249-254, 2014.

[9] H. Abdelhafez and M. Abdallah, "Making It 'Authentic': Egyptian EFL Student Teachers' Awareness and Use of Online Authentic Language Materials and Their Learning Motivation," J. Res. Curric. Instr. Educ. Technol., vol. 1, no. 1, pp. 129-168, 2015.

[10] L. Dee Fink, "Editorial," New Dir. Teach. Learn., no. 119, pp. 1-7, 2009.

[11] H. Fry, S. Ketteridge, and S. Marshall, $A$ Handbook for Teaching and Learning: Enhancing Academic Pratice. 2015.

[12] A. Sonia and H. Fisher, "Students ' Reading Techniques Difficulties in Recount Text," English Educ., vol. 4, no. 2, pp. 1-12, 2009.

[13] H. Camacho and E. Christiansen, "Teaching Critical Thinking within an Institutionalised Problem Based Learning Paradigm -- Quite a Challenge.," J. Probl. Based Learn. High. Educ., vol. 6, no. 2, pp. 91-109, 2018. 